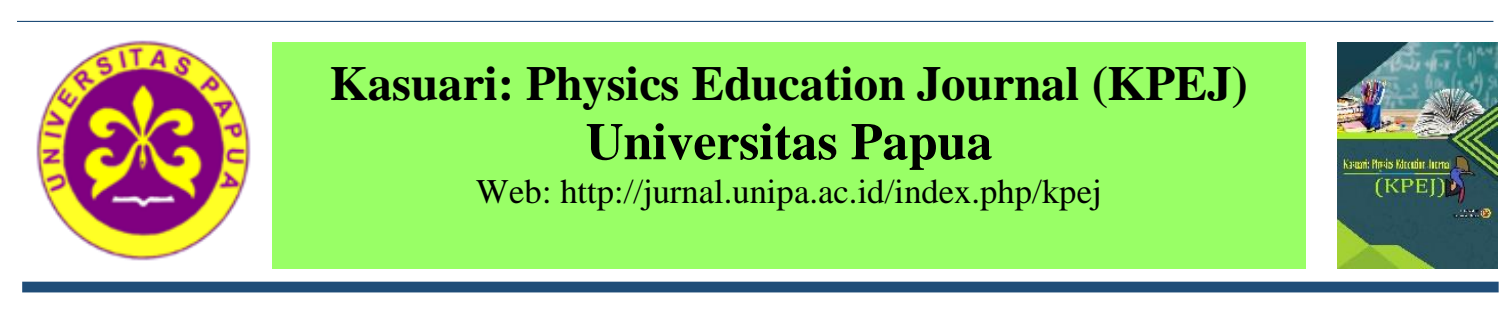

\title{
How Results of The Ability to Understand Physics on Newton's Motion Law Material using Guided Inquiry?
}

\author{
Ma'ruf $^{1 *}$, Novita Maumude ${ }^{2}, \&$ Khaeruddin ${ }^{3}$ \\ ${ }^{1,2}$ Pendidikan Fisika, FKIP, Universitas Muhammadiyah Makassar \\ ${ }^{3}$ Jurusan Fisika, FMIPA, Universitas Negeri Makassar \\ *maruf@unismuh.ac.id
}

\begin{abstract}
The main problem in this research is how the results of the level of understanding of physics concepts on the aspect of translation through the guided incuri learning model? The type of this research is True Experimental Design by using Posttest-Only Control Design. The research instrument used was a test of understanding the concept of the translational aspects of physics in the form of essay questions. The population is 120 students from class X of SMKN Buyasuri, and the sample is X class students "Ruminansia" totaling 30 people and "Poultry" totaling 30 people. The analysis technique used is descriptive analysis and inferential analysis through normality test, homogeneity test, and hypothesis testing. The results of descriptive statistical analysis showed that the level of understanding the concept of the physics translation aspects of class $X$ students in Ruminansia that were taught using the guided inquiry model obtained an average score of 85.33 and a standard deviation of 7.63 and an understanding of the concept of the physics translation aspects of Poultry class students taught without using the guided inquiry model obtained an average score of 70.33 and a standard deviation of 9.90. While the results of inferential statistical analysis show that the two classes come from homogeneous normally distributed populations and the value of $t_{\text {count }}>t_{\text {table }}$ is $6.474>1.673$.
\end{abstract}

Keywords: Guided Inquiry, Concept Understanding, and Translational Aspects of Physics

\section{Bagaimana Hasil Kemampuan Pemahaman Konsep Fisika pada Konsep Hukum Gerak Newton menggunakan Inquiry Terbimbing?}

\begin{abstract}
Abstrak: Masalah utama dalam penelitian ini yaitu bagaimana hasil tingkat pemahaman konsep fisika pada aspek translasi melalui model pembelajaran inkuri terbimbing? Jenis penelitian ini adalah True Experimental Design dengan menggunakan desain Posttest-Only Control Design. Instrumen penelitian yang digunakan adalah tes pemahaman konsep aspek translasi fisika dalam bentuk soal essay. Populasi adalah 120 peserta didik dari kelas X SMKN Buyasuri, dan sampelnya yaitu peserta didik kelas X Ruminansia berjumlah 30 orang dan Unggas berjumlah 30 orang. Teknik analisis yang digunakan adalah analisis deskriptif dan analisis inferensial melalui uji normalitas, uji homogenitas, dan uji hipotesis. Hasil analisis statistik deskriptif menunjukkan bahwa tingkat pemahaman konsep aspek translasi fisika peserta didik kelas X Ruminansia yang diajar menggunakan model inkuiri terbimbing memperoleh skor rata-rata 85,33 dan standar deviasi 7,63 dan pemahaman konsep aspek translasi fisika peserta didik kelas Unggas yang diajar tanpa menggunakan model inkuiri terbimbing memperoleh skor rata-rata 70,33 dan standar deviasi 9,90. Sedangkan hasil analisis statistik inferensial menunjukkan bahwa kedua kelas berasal dari populasi berdistribusi normal yang homogen dan diperoleh nilai $t_{\text {hitung }}>t_{\text {tabel }}$ yaitu 6,474 >1,673.
\end{abstract}

Kata kunci: Inkuiri Terbimbing, Pemahaman Konsep, dan Aspek Translasi Fisika 


\section{PENDAHULUAN}

Fisika biasa disebut sains yang merupakan cabang dari Ilmu Pengetahuan Alam yang sangat memegang peranan penting dalam bidang teknologi. Dimana pada tingkatan jenjang pendidikan Sekolah Menengah Atas (SMA) dihadapkan pada proses pembelajaran yang diharuskan peserta didik lebih berperan aktif di kelas yang sesuai dengan tuntunan kurikulum yang ada (Syam, Arsyad, \& Maruf, 2015). Proses belajar yang dilakukan pada jenjang ini sangat mempengaruhi keberhasilan belajar pada jenjang berikutnya, sehingga peserta didik dituntun untuk memahami konsep-konsep fisika dengan cara menemukan sendiri cara menyelesaikan suatu masalah yang mereka temukan. Maka pengetahuan yang diperoleh dari proses belajar maupun pengalaman belajar, akan lebih bermakna sehingga perlu diterapkan suatu metode mengajar yang sesuai dengan materi yang diajarkan (Ahriana, Yani, \& Maruf, 2016). Pembelajaran dipandang memiliki kualitas baik jika interaksi yang terjadi bersifat multi arah, yakni guru-siswa, siswa-guru, siswasiswa, siswa-sumber belajar, dan siswa-lingkungan belajar (Ayu, Ariani, \& Arini, 2019).

Berdasarkan observasi yang dilakukan peneliti, pembelajaran yang berlangsung di SMKN Buyasuri khususnya pada mata kelas X Ruminansia dan X Unggas terutama pada pemahaman konsep peserta didik pada materi fisika masih rendah. Hal ini dapat dilihat bagaimana peserta didik yang diajarkan lebih menekan pada pemahaman secara abstrak atau lebih kepenghafalan materi tanpa melakukan suatu penyelidikan terhadap materi fisika tersebut. Sehingga peserta didik akan sulit menjelaskan kembali keterkaitan suatu konsep-konsep fisika yang dipelajari dengan penerapan konsep fisika dalam kehidupan sehari-hari sehingga meyebabkan miskonsepsi peserta didik. Miskonsepsi pada peserta didik mengakibatkan peserta didik memiliki masalah pada pemahaman konsepnya.

Masalah yang dialami peserta didik karena kurangnya pemahaman konsep dan ketertarikan peserta didik terhadap pelajaran fisika, serta daya tangkap peserta didik yang berbeda-beda (Ma'ruf, Marisda, \& Handayani, 2019). Sehingga penulis mencoba untuk membuat peserta didik paham bukan hanya sebagai konsep saja melainkan mempraktekannya, sehingga peserta didik yang memiliki pemahaman daya tangkap kurang apabila guru hanya menggunakan pembelajaran konvensional saja terhadap pelajaran fisika (Ariansyah, Khaeruddin, \& Maruf, 2015).

Oleh karena itu, dibutuhkan sebuah model pembelajaran yang dinama lebih melibatkan peserta didik secara langsung untuk melakukan penyelidikan terhadapsuatukonsep materi fisika, namun dalam penyelidikan konsep materi fisika tidak terlepas dari bimbingan atau arahan dari guru, dengan model pembelajaran ini diharapkan peserta didik lebih menemukan kebermaknaan dalam proses pembelajaran (Ma'ruf, Handayani, Marisda, \& Riskawati, 2020).

\section{LANDASAN TEORI}

\section{Model pembelajaran inkuiri terbimbing}

Inkuiri terbimbing (Guide Inkuiri) merupakan salah satu proses untuk memperoleh dan mendapatkan informasi dengan melakukan obeservasi atau eksperimen untuk mencari jawaban terhadap suatu pertanyaan atau rumusan masalah yang mengarahkan pada suatu diskusi (Kurniawan, 2012). Siswa dituntut untuk menemukan konsep melalui petunjuk dari guru. Petunjuk-petunjuk itu umumnya berupa pertanyaan-pertanyaan yang bersifat membimbing. Model inkuiri terbimbing yaitu model inkuiri dimana guru membimbing siswa melakukan kegiatan dengan memberi pertanyaan awal dan mengarahkan pada suatu diskusi dan guru juga memberikan penjelasa-penjelasan seperlunya pada saat siswa melakukan percobaan. Guru mempunyai peran akrif dalam 
menentukan permasalahan dan tahap-tahap pemecahannya (Puspita, \& Jatmiko, 2013). Inkuiri terbimbing adalah suatu model pembelajaran inkuiri yang dalam praktiknya guru menyediakan dan petunjuk bagi siswa. Peran guru dam model ini lebih dominan dari pada siswa. Guru membuat rumusan masalah, lalu menyerahkan kepada siswa. Guru tidak langsung melepaskan segala kegiatan yang dilakukan siswa (Pransiska, Amin, \& Gumay, 2019). Inkuiri terbimbing biasanya digunakan pada siswa yang belum pernah melakukan model inkuri. Jadi banyak bimbingan dan arahan sebagai awal untuk menuju pada model pembelajaran yang benar-benar mandiri (Sahriani, Arsyad, \& Maruf, 2016). Jadi dapat disimpulkan bahwa model pembelajaran inkuiri terbimbing adalah model pembelajaran yang melibatkan siswa secara langsung untuk menyelidiki suatu konsep dalam pembelajaran namun tidak terlepas dari bimbingan dan arahan seorang guru, dengan model pembelajaran ini siswa akan menemukan kebermaknaan dalam proses pembelajaran (Nuraisyah, Samad, \& Maruf, 2016).

\section{Pemahaman Konsep Fisika}

Pemahaman diartikan sebagai kemampuan untuk menyerap arti dari materi atau bahan yang dipelajari. Pemahaman menurut Bloom ini adalah seberapa besar siswa mampu menerima, menyerap dan memahami pelajaran yang diberikan oleh guru kepada siswa, atau sejauh mana siswa dapat memahami serta mengerti apa yang ia baca, yang dilihat, yang dialami, atau yang dirasakan berupa hasil penelitian atau observasi langsung yang ia lakukan. Pada aspek pemahaman adalah kemampuan mendapatkan penekanan dalam proses belajar-mengajar (Irwandani, 2015). Pemahaman konsep bersangkutan dengan inti dari sesuatu, ialah suatu bentuk pengertian atau pemahaman yang menyebabkan sesorang mengetahui apa yang sedang dikomunikasikan, dan dapat menggunakan bahan atau ide yang sedang dikomunikasikan itu tanpa harus menghubungkannya dengan bahan lain. Pemahaman di bedakan menjadi tiga yakni : penerjemahan yaitu menerjemahkan konsepsi abstrak menjadi suatu model, penafsiran yaitu kemampuan untuk mengenal dan memahami ide utama suatu komunikasi, dan ekstrapolasi yaitu menyimpulkan dari suatu konsep yang telah diketahui (Chasanah, Mujasam, Widyaningsih, \& Yusuf, 2019). Dari ketiga aspek pemahaman konsep yang telah diuraikan diatas. Aspek penerjemah yang digunakan. Dalam aspek penerjemah (translasi) terdiri dari tiga sub indikator yakni : kemampuan menerjemahkan ilustrasi/gambar, kemampuan menerjemahkan tabel/grafik, kemampuan menerjemahkan persamaan atau rumus-rumus lainnya (Iklashi, Mujasam, Yusuf, \& Widyaningsih, 2019).

\section{METODE PENELITIAN}

Jenis penelitian yang digunakan adalah true experimental designs dengan menggunakan posttest-only control design. Lokasi bertempat di SMKN Buyasuri yang beralamat di Jalan Trans Buyasuri Desa Atulaleng Kecamatan Buyasuri. Variabel Penelitian yang akan diteliti ada dua yaitu: variabel bebas model pembelajaran inkuiri terbimbing dan variabel terikat yaitu pemahaman konsep aspek translasi fisika. Instrumen penelitian yaitu berupa tes pemahaman konsep aspek translasi peserta didik SMKN Buyasuri, peneliti menggunakan instrumen berupa essay tes pada pokok bahasan dinamika gerak (hukum gerak newton dan penerapannya) yang ada pada semester ganjil dengan $\mathrm{C} 2=15$ soal dengan indikator yang digunakan yaitu indikator translasi. Adapun tahapan penyusunan dan pengembangan instrumen penelitian ini adalah menyusun kisikisi soal instrumen tes pemahaman konsep aspek translasi fisika, menyusun soal instrumen tes pemahaman konsep aspek translasi fisika (posttest) pada materi dinamika gerak (Hukum Newton tentang gerak dan penerapannya), dan melakukan uji validasi dan 
reliabitas instrumen penelitian. Uji validitas digunakan untuk mengetahui kualitas terhadap instrumen yang digunakan dalam penelitian ini. Pengujian validitas setiap butir soal atau item instrumen dimaksudkan untuk menguji kesejajaran atau korelasi skor instrumen dan skor total instrumen yang diperoleh dengan mengkorelasikan antara skor yang diperoleh masing-masing item pertanyaan dengan skor total individu. Pengambilan keputusan berdasarkan pada $\mathrm{r}_{\text {hitung }}>\mathrm{r}_{\text {tabel. }}$. Sedangkan uji reliabilitas untuk mengetahui apakah instrumen yang digunakan dalam penelitian ini dapat dipercaya sebagai alat pengumpul data, maka harus ditentukan reliabilitasnya. Untuk Perhitungan reliabilitas tes didekati dengan rumus Cronbach Alpha (Ma'ruf, 2018).

\section{HASIL DAN PEMBAHASAN}

Kegiatan penelitian yang dilakukan di dalam kelas dengan menggunakan tahapan model pembelajaran inkuiri terbimbing untuk materi dinamika gerak (Hukum Newton tentang gerak dan penerapannya), dan diakhir kegiatan dilakukan pemberian tes pemahaman konsep aspek translasi fisika dengan menggunakan tiga indikator sesuai dengan yang ada di Tabel 1 .

Tabel 1. Analisis persentase skor rata-rata kemampuan pemahaman konsep fisika aspek translasi pada konsep hukum gerak newton

\begin{tabular}{|l|l|c|c|}
\hline \multirow{2}{*}{ No } & \multicolumn{1}{|c|}{ Indikator } & \multicolumn{2}{c|}{ Persentase (\%) } \\
\cline { 3 - 4 } & \multicolumn{1}{|c|}{ Eks. } & Kontrol \\
\hline 1 & $\begin{array}{l}\text { Kemampuan menerjemahkan sebuah ilustrasi/gambar } \\
\text { kedalam bentuk verbal }\end{array}$ & 16,8 & 13,8 \\
\hline 2. & $\begin{array}{l}\text { Kemampuan menerjemahkan sebuah persamaan atau } \\
\text { rumus-rumus lain bentuk verbal }\end{array}$ & 50,0 & 48,1 \\
\hline 3. & $\begin{array}{l}\text { Kemampuan menerjemahkan sebuah tabel kedalam } \\
\text { bentuk verbal }\end{array}$ & 71,3 & 48,5 \\
\hline
\end{tabular}

Adapun diagram skor rata-rata per masing-masing indikator pemahaman konsep pada aspek translasi yakni kemampuan menerjemahkan sebuah ilustrasi/gambar kedalam bentuk verbal, kemampuan menerjemahkan sebuah persamaan atau rumus-rumus lain bentuk verbal, dan kemampuan menerjemahkan sebuah tabel kedalam bentuk verbal dapat dilihat pada Gambar 1.

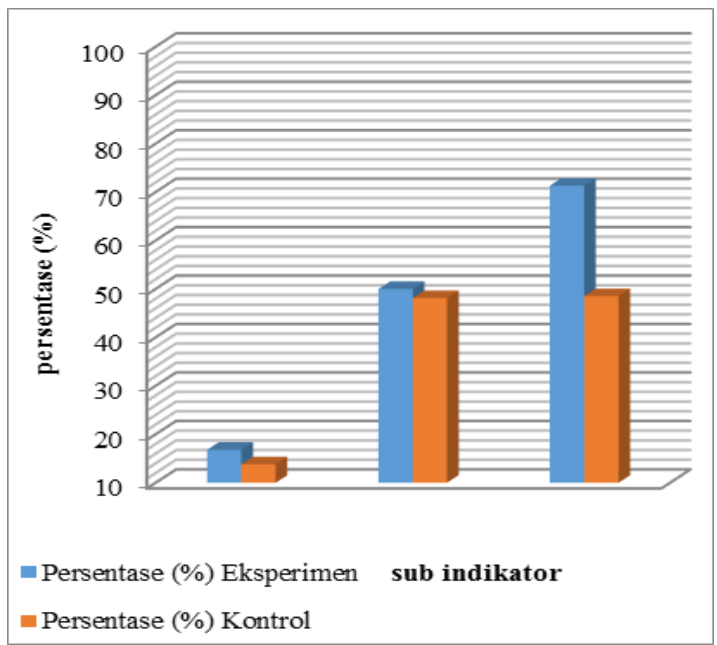

Gambar 1. Grafik persentase skor rata-rata kemampuan pemahaman konsep fisika hukum gerak newton 
Hasil analisis deskriptif pada penelitian ini sebagai gambar dasar dari data hasil penelitian yang terdiri dari subjek, standar deviasi, skor tertinggi, skor terendah, rentag data, banyaknya kelas interval, panjang kelas, skor rata-rata, skor manimum, skor ideal dan varians dapat dilihat pada Tabel 2 .

Tabel 2. Deskripsi hasil pemahaman konsep aspek translasi fisika peserta didik kelas $X$ SMKN Buyasuri

\begin{tabular}{|c|c|c|}
\hline Statistik & Kelas Eksperimen & Kelas Kontrol \\
\hline Subjek & 30,00 & 30,00 \\
\hline Standar deviasi & 7,63 & 9,90 \\
\hline Skor tertinggi & 100,00 & 87,00 \\
\hline Skor terendah & 71,00 & 52,00 \\
\hline Rentang data & 29,00 & 35,00 \\
\hline Banyak kelas interval & 6,00 & 6,00 \\
\hline Panjang kelas interval & 5,00 & 6,00 \\
\hline Skor rata-rata & 85,33 & 70,30 \\
\hline Skor minimum & 0,00 & 0,00 \\
\hline Skor ideal & 100,00 & 00,00 \\
\hline Varians & 58,16 & 98,03 \\
\hline
\end{tabular}

Berdasarkan Tabel 2 dapat diketahui bahwa, analisis deskriptif data posttest pada kelas eksperimen memperoleh skor rata-rata yaitu 85,33 dengan standar deviasi 7,63. Skor tertinggi yang diperoleh peserta didik pada kelas eksperimen yaitu 100 dan skor terendah 71. Sedangkan data posttest untuk kelas kontrol memperoleh skor rata-rata yaitu 70,30 dengan standar deviasi 9,90. Skor tertinggi yang diperoleh peserta didik pada kelas kontrol yaitu 87 dengan skor terendah 52 .

Tabel 3. Persentase distribusi frekuensi dan kategorisasi skor kelas eksperimen dan kelas kontrol

\begin{tabular}{|c|c|c|c|c|c|}
\hline \multirow{2}{*}{$\begin{array}{c}\text { Interval } \\
\text { skor }\end{array}$} & \multirow{2}{*}{ Kategori } & \multicolumn{2}{|c|}{ Frekuensi } & \multicolumn{2}{c|}{ Persentase (\%) } \\
\cline { 3 - 6 } & & Eksperimen & Kontrol & Eksperimen & Kontrol \\
\hline $18-34$ & Sangat rendah & 0,00 & 0,00 & 0,00 & 0,00 \\
\hline $35-51$ & Rendah & 0,00 & 0,00 & 0,00 & 0,00 \\
\hline $52-68$ & Sedang & 0,00 & 13,00 & 0,00 & 43,33 \\
\hline $69-85$ & Tinggi & 13,00 & 12,00 & 43,33 & 40,00 \\
\hline $86-100$ & Sangat tinggi & 17,00 & 5,00 & 56,67 & 16,67 \\
\hline \multicolumn{2}{|c|}{ Jumlah } & 30,00 & 30,00 & 100,00 & 100,00 \\
\hline
\end{tabular}

Adapun diagram kategorisasi skor dan frekuensi pemahaman konsep aspek translasi fisika peserta didik pada kelas eksperimen dan kelas kontrol dapat dilihat pada Gambar 2. 


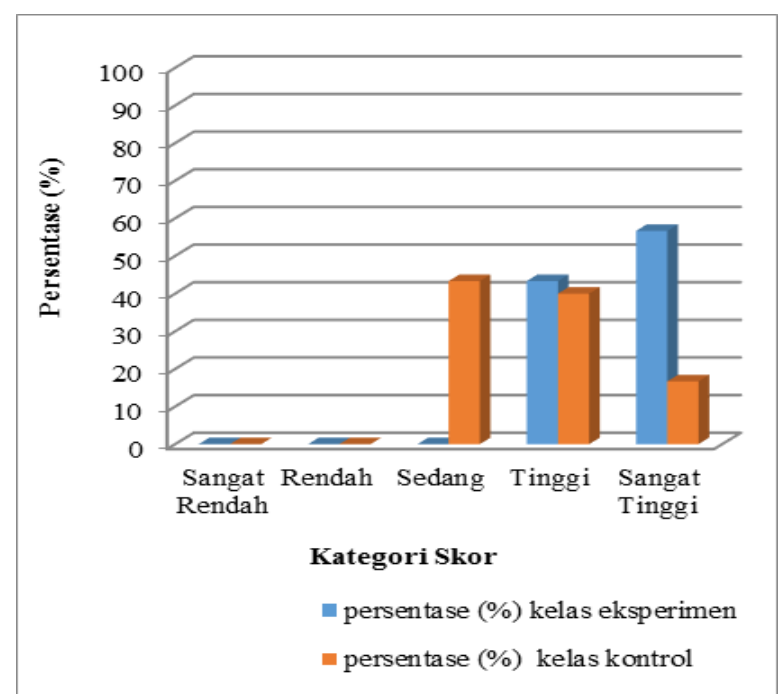

Gambar 2. Grafik persentase pengkategorian skor dan frekuensi pemahaman konsep aspek translasi fisika

Gambar 2 menunjukkan bahwa pada kelas eksperimen tidak ada peserta didik yang memperoleh skor dengan kategori sangat rendah, rendah dan sedang. Pada rentang skor kategori tinggi peserta didik memperoleh persentase sebesar 43,33\%, dan pada rentang skor kategori sangat tinggi persentase yang diperoleh pesera didik sebesar 56,67\%. Sedangkan untuk kelas kontrol tidak ada peserta didik yang memperoleh skor dengan kategori sangat rendah dan rendah, pada rentang skor dengan kategori sedang persentase yang diperoleh peserta didik 43,33\%. Pada rentang skor dengan kategori tinggi peserta didik memperoleh persentase $40,00 \%$, pada rentang skor dengan kategori sangat tinggi persentase yang diperoleh pesera didik sebesar $16,67 \%$.

Pengujian normalitas menunjukan bahwa nilai $\chi_{\text {hitung }}^{2}$ sebesar 3,330 sedangkan nilai $\chi_{\text {tabel }}^{2}$ untuk $\alpha=0,05$ dan derajat kebebasan $(\mathrm{dk})=2$, maka dicari pada tabel chi kuadrat didapat $\chi_{\text {tabel }}^{2}=\chi_{(1-\alpha) d k}^{2}=\chi_{(1-0,05)(2)}^{2}=\chi_{(0,95)(2)}^{2}=5,991$ dengan kriteria pengujian, jika $\chi_{\text {hitung }}^{2} \geq \chi_{\text {tabel }}^{2}$ artinya distribusi data tidak normal dan jika $\chi_{\text {hitung }}^{2} \leq \chi_{\text {tabel }}^{2}$, artinya data berdistribusi normal. Ternyata $\chi_{\text {hitung }}^{2} \leq \chi_{\text {tabel }}^{2}$ atau $3,330 \leq 5,991$. Sehingga dapat disimpulkan kelas eksperimen merupakan kelompok data yang berasal dari populasi berdistribusi normal. Sedangkan pada kelas kontrol diperoleh $\chi_{\text {hitung }}^{2}$ sebesar 6,185 dan nilai $\chi_{\text {tabel }}^{2}$ untuk $\alpha=0,05$ dan derjat kebebasan $(\mathrm{dk})=3$, maka dicari pada tabel chi kuadrat didapat $\chi_{\text {tabel }}^{2}=\chi_{(1-\alpha) d k}^{2}=\chi_{(1-0,05)(3)}^{2}=\chi_{(0,95)(3)}^{2}=7,815$ dan hasilnya menunjukkan bahwa $\chi_{\text {hitung }}^{2} \leq \chi_{\text {tabel }}^{2}$ atau $6,185 \leq 7,815$. Sehingga dapat disimpulkan bahwa kelas kontrol merupakan kelompok dari data yang berasal dari populasi berdistribusi normal. Perhitungan pengujian homogenitas varians diperoleh nilai $F_{\text {hitung }}=1,69$ dan nilai $F_{\text {tabel }}=1,86$, karena $F_{\text {hitung }}<F_{\text {tabel, }}$ maka disimpulkan bahwa data skor pemahaman konsep aspek translasi fisika peserta didik kelompok yang diajar dengan menggunakan model pembelajaran inkuiri terbimbing dan kelompok yang diajar menggunakan pembelajaran konvensional berasal dari populasi yang mempunyai varians yang homogen.

Berdasarkan hasil penelitian dari analisis skor rata-rata sub indikator, maka dapat dideskripsikan dengan menggunakan analisis statistik deskriptif yang menunjukkan bahwa skor rata-rata pemahaman konsep aspek translasi fisika di kelas kontrol lebih banyak peserta didik memperoleh skor pada kategori sedang. Sedangkan pemahaman 
konsep aspek translasi fisika yang diperoleh peserta didik di kelas eksperimen lebih banyak memperoleh skor pada kategori sangat tinggi. Hasil analisis selanjutnya adalah analisis inferensial yang digunakan untuk menguji normalitas data penelitian, menguji homogenitas data, serta terakhir untuk menguji hipotesis dimana uji hipotesis menggunakan uji-t pihak kanan. Pada uji normalitas dilakukan pada kelas eksperimen dan kelas kontrol dan menunjukkan bahwa kedua kelas tersebut berasal dari populasi yang berdistribusi normal. Analisis yang kedua yaitu uji homogenitas yang menunjukkan bahwa kelas tersebut berasal dari kelas yang homogen.

Pengujian hipotesis penelitian degan menggunakan uji-t, diperoleh skor thitung diperoleh sebesar 6,474, sedangkan untuk $\mathrm{t}_{\text {tabel }}$ dengan $\mathrm{dk}=\left(\mathrm{n}_{1}+\mathrm{n}_{2}-2\right)=30+30-2=$ 56. Pada taraf nyata $\alpha=0,05$ diperoleh $t_{\text {tabel }}=(0,95)(56)$ sebesar 1,673 . Hasil yang diperoleh menunjukkan $t_{\text {hitung }}>t_{\text {tabel }}=6,474>1,673$ yang artinya $H_{o}$ ditolak dan $H_{a}$ diterima. Terdapat perbedaan pemahaman konsep aspek translasi fisika peserta didik yang diajar dengan menggunakan model pembelajaran inkuiri terbimbing dan menggunakan metode ceramah sebagai pembelajaran konvensional. Penelitian mengenai model pembelajaran inkuiri terbimbing terhadap pemahaman konsep memperlihatkan adanya peningkatan antara pemahaman konsep siswa terhadap hasil belajar (Kurniawan, W, 2012). Peningkatan pemahaman konsep peserta didik dapat meningkat hasil belajar mereka (Yusuf \& Widyaningsih, 2018). Model pembelajaran inkuiri dapat melatih peserta didik untuk menemukan sendiri suatu konsep sehingga hasil belajar mereka meningkat (Nuraisyah, Samad, \& Maruf, 2016). Berdasarkan hal tersebut diperoleh bahwa model pembelajaran inkuiri terbimbing berpengaruh terhadap pemahaman konsep peserta didik. Dengan demikian model pembelajaran inkuiri terbimbing dapat dijadikan sebagai salah satu alternatif dalam proses belajar mengajar untuk meningkatkan pemahaman peserta didik.

\section{SIMPULAN DAN SARAN}

Berdasarkan hasil analisis data dan pembahasan hasil penelitian, dapat disimpulkan bahwa terdapat perbedaan pemahaman konsep aspek translasi fisika peserta didik yang diajar dengan menggunakan model pembelajaran inkuiri terbimbing dan menggunakan metode ceramah sebagai pembelajaran konvensional.

\section{DAFTAR PUSTAKA}

Ahriana, A., Yani, A., \& Maruf, M. (2016). Studi Analisis Hubungan Antara Self Efficacy dengan Hasil Belajar Fisika Siswa Kelas XI MIA SMA Negeri 1 Takalar. Jurnal Pendidikan Fisika, 4(2), 223-238.

Ariansyah, A., Khaeruddin, K., \& Maruf, M. (2015). Upaya Meningkatkan Hasil Belajar Fisika Melalui Pembelajaran Kontekstual Pada Siswa Kelas VII SMP Aisyiyah Paccinongang. Jurnal Pendidikan Fisika, 3(2), 91-104.

Ayu, W. R., Ariani, T., \& Arini, W. (2019). The Effect of Quantum Teaching Learning Model on the Physics Learning Outcomes of Class X SMK Negeri 3 Lubuklinggau. Kasuari: Physics Education Journal (KPEJ), 2(1), 36-48.

Chasanah, R. N., Mujasam, M., Widyaningsih, S. W., \& Yusuf, I. (2019). Influence of The Use Of Interactive Learning Media On Students' Higher Order Thinking Skills. Kasuari: Physics Education Journal (KPEJ), 2(1), 26-35.

Iklashi, R., Mujasam, M., Yusuf, I., \& Widyaningsih, S. W. (2019). Contribution Analisis of Scientific Attitudes Towards Student Achievements Department of Physics Education in Universitas Papua. Kasuari: Physics Education Journal (KPEJ), 2(2), 95-109. 
Irwandani, I. (2015). Pengaruh Model Pembelajaran Generatif Terhadap Pemahaman Konsep Fisika Pokok Bahasan Bunyi Peserta Didik MTs Al-Hikmah Bandar Lampung. Jurnal Ilmiah Pendidikan Fisika Al-Biruni, 4(2), 165-177.

Kurniawan, W. (2012). Pembelajaran fisika dengan metode inquiry Terbimbing untuk mengembangkan Keterampilan proses sains. Jurnal Penelitian Pembelajaran Fisika, 1(2).

Ma'ruf, M., Handayani, Y., Marisda, D. H., \& Riskawati, R. (2020). The needs analysis of basic physics learning devices based on hybrid learning. In Journal of Physics: Conference Series (Vol. 1422, No. 1, p. 012029). IOP Publishing.

Ma'ruf, M. (2018). Statistika Dasar untuk Penelitian Pendidikan Fisika. Makassar: LPP Unismuh Makassar.

Ma'ruf, M., Marisda, D. H., \& Handayani, Y. (2019). The basic physical program based on education model online assisted by alfa media to increase creative thinking skills. In Journal of Physics: Conference Series (Vol. 1157, No. 3, p. 032068). IOP Publishing.

Nuraisyah, N., Samad, A., \& Maruf, M. (2016). Upaya Meningkatkan Hasil Belajar Fisika Melalui Model Pembelajaran Inquiry Terbimbing Pada Peserta Didik Kelas VIII SMP Muhammadiyah Limbung. Jurnal Pendidikan Fisika, 4(2), 209222.

Pransiska, P., Amin, A., \& Gumay, O. P. U. (2019). The Effectiveness of Contextual based Textbooks on the Amount and Measurement Material of Class X Students of Tugumulyo Senior High School. Kasuari: Physics Education Journal (KPEJ), 2(2), 82-88.

Puspita, A. T., \& Jatmiko, B. (2013). Implementasi model pembelajaran inkuiri terbimbing (guided inquiry) terhadap keterampilan berpikir kritis siswa pada pembelajaran fisika materi fluida statis kelas XI di SMA Negeri 2 Sidoarjo. Inovasi Pendidikan Fisika, 2(3).

Sahriani, I., Arsyad, M., \& Maruf, M. (2016). Peningkatan Hasil Belajar Fisika Melalui Model Pembelajaran Tandur Berbasis Inkuiri Pada Siswa Kelas XI. IPA1 SMA Negeri 1 Bungoro. Jurnal Pendidikan Fisika, 4(1), 112-126.

Syam, M., Arsyad, M., \& Maruf, M. (2015). Peranan penggunaan KIT IPA sebagai alat pembelajaran dalam upaya menigkatkan keterampilan peserta didik kelas VIII4 SMP Negeri 1 Belawa Kabupaten Wajo. Jurnal Pendidikan Fisika, 3(3), 241-262.

Yusuf, I., \& Widyaningsih, S. W. (2018). Profil kemampuan mahasiswa dalam menyelesaikan soal HOTS di Jurusan Pendidikan Fisika Universitas Papua. Jurnal Komunikasi Pendidikan, 2(1), 42-49. 